\title{
Omega-3 Fatty Acids and Antioxidants in Edible Wild Plants
}

\author{
ARTEMIS P SIMOPOULOS
}

The Center for Genetics, Nutrition and Health, Washington, DC, USA

\begin{abstract}
Human beings evolved on a diet that was balanced in the omega- 6 and omega- 3 polyunsaturated fatty acids (PUFA), and was high in antioxidants. Edible wild plants provide alpha-linolenic acid (ALA) and higher amounts of vitamin $\mathrm{E}$ and vitamin $\mathrm{C}$ than cultivated plants. In addition to the antioxidant vitamins, edible wild plants are rich in phenols and other compounds that increase their antioxidant capacity. It is therefore important to systematically analyze the total antioxidant capacity of wild plants and promote their commercialization in both developed and developing countries. The diets of Western countries have contained increasingly larger amounts of linoleic acid (LA), which has been promoted for its cholesterol-lowering effect. It is now recognized that dietary LA favors oxidative modification of low density lipoprotein (LDL) cholesterol and increases platelet response to aggregation. In contrast, ALA intake is associated with inhibitory effects on the clotting activity of platelets, on their response to thrombin, and on the regulation of arachidonic acid (AA) metabolism. In clinical studies, ALA contributed to lowering of blood pressure, and a prospective epidemiological study showed that ALA is inversely related to the risk of coronary heart disease in men. Dietary amounts of LA as well as the ratio of LA to ALA appear to be important for the metabolism of ALA to longer-chain omega-3 PUFAs. Relatively large reserves of LA in body fat, as are found in vegans or in the diet of omnivores in Western societies, would tend to slow down the formation of long-chain omega3 fatty acids from ALA. Therefore, the role of ALA in human nutrition becomes important in terms of longterm dietary intake. One advantage of the consumption of ALA over omega-3 fatty acids from fish is that the problem of insufficient vitamin E intake does not exist with high intake of ALA from plant sources.
\end{abstract}

Key words: Alpha-linolenic acid, antioxidants, chronic diseases, edible wild plants, evolutionary aspects of diet, omega-3 fatty acids.

\begin{abstract}
Abbreviations: AA: arachidonic acid; AI: Adequate Intake; ALA: alpha-linolenic acid; ARP: antiradical power; DHA: docosahexaenoic acid; DPPH': 2,2-diphenyl-1-picrylhydrazyl; FRAP: ferric-reducing ability of plasma; LA: linoleic acid; LDL: low density lipoprotein; EPA: eicosapentaenoic acid; ORAC: oxygen radical absorbance assay; PUFA: polyunsaturated fatty acids.
\end{abstract}

\section{INTRODUCTION}

In nutritional terms, human physiology evolved in the context of wild plants and animals in the wild. Most likely, human beings made use of both aquatic and terrestrial foods. Over the past 20 years, many studies and clinical investigations have been carried out on the metabolism of polyunsaturated fatty acids (PUFAs) in general and on omega-3 fatty acids in particular. Today we know that omega-3 fatty acids are essential for normal growth and development and may play an important role in the prevention and treatment of coronary artery disease, hypertension, diabetes, arthritis, other inflammatory and autoimmune disorders, and cancer (1-10). Research has been carried out in animal models, tissue cultures, and human beings. The original observational studies have given way to controlled clinical trials. Great progress has taken place in our knowledge of the physiologic and molecular mechanisms of the various fatty acids in health and disease. Specifically, their beneficial effects have been 
shown in the prevention and management of coronary heart disease (11-14), hypertension (15-17), type 2 diabetes $(18,19)$, renal disease $(20,21)$, rheumatoid arthritis (22), ulcerative colitis (23), Crohn's disease (24), and chronic obstructive pulmonary disease (25). Epidemiologic studies indicate that fruits and vegetables decrease the risk of chronic diseases, including cancer, cardiovascular and cerebrovascular disease. This protection has been attributed to the various antioxidants contained in them (26-29).

Oxidative damage, as a result of normal metabolism or secondary to environmental pollutants, leads to free radical formation which has been considered to play a central role in cancer and atherosclerosis. Therefore, antioxidants, which can neutralize free radicals, may be important in the prevention of these diseases. However, results from intervention trials with single compounds such as vitamins E and $\mathrm{C}$ or beta-carotene have not supported any protective effect (30-36). In fact, supplementation with beta-carotene resulted in adverse disease outcomes in clinical trials (37-40). One reason for the ineffective clinical trials may be the fact that the protective effects of fruits and vegetables most likely result from the action of lesser known antioxidant compounds, or from a mixture of antioxidants present in foods. Thus, a number of dietary antioxidants, such as flavonoids, carotenoids, polyphenols and sulfides, etc., are bioactive and work synergistically as do vitamin $\mathrm{C}$ and vitamin E. This hypothesis led to the thinking that the total amount of electron-donating antioxidants in the diet, derived from a combination of various antioxidants occurring naturally in foods, need to be determined. A number of methods have been used to assess the total antioxidant capacity of dietary plants (41-43). This paper focuses on omega-3 fatty acids and antioxidants in edible wild plants.

\section{EVOLUTIONARY ASPECTS OF DIET}

On the basis of estimates from studies in Paleolithic nutrition and modern-day hunter-gatherer populations, it appears that human beings evolved consuming a diet that was much lower in saturated fatty acids than is today's diet (44). Furthermore, the diet contained small and roughly equal amounts of omega- 6 and omega- 3 PUFAs (ratio of 1-2:1) and much lower amounts of trans fatty acids than does today's diet (Fig. 1) $(45,46)$. Wild plants contributed higher amounts of vitamin $\mathrm{E}$ and vitamin $\mathrm{C}$, and other antioxidants than cultivated plants, providing additional protection against cancer and atherosclerosis (7).

The current Western diet is very high in omega- 6 fatty acids (the ratio of omega- 6 to omega-3 fatty acids is $10-20: 1$ ) because of the indiscriminate recommendation to substitute omega- 6 fatty acids for saturated fats to lower serum cholesterol concentrations (48). Table I compares the omega-6: omega-3 intake of various populations (49-53). The population of Crete obtained a higher intake of alpha-linolenic acid (ALA) from purslane and other wild plants, walnuts and figs, whereas the Japanese obtained it from canola oil and soybean oil (49).

Intake of omega-3 fatty acids is much lower today because of the decrease in fish consumption and the industrial production of animal feeds rich in grains containing omega- 6 fatty acids, leading to production of meat rich in omega- 6 and poor in omega3 fatty acids (54). The same is true for cultured fish (55) and eggs (56). Even cultivated vegetables contain fewer omega3 fatty acids than do plants in the wild (57, 58). In summary, modern agriculture, with its emphasis on production, has decreased the omega-3 fatty acid content in many foods: green leafy vegetables, animal meats, eggs, and even fish. Although RDAs do not officially exist, the Adequate Intake (AI) of essential fatty acids has been established (59) as well as the ratio of $18: 2 \omega 6$ to $18: 3 \omega 3(60)$.

EFFECTS OF DIETARY ALA COMPARED WITH LONG-CHAIN OMEGA-3 FATTY ACID DERIVATIVES ON PHYSIOLOGIC INDEXES

Several clinical and epidemiologic studies have been conducted to determine the effects 


\section{Hunter Gatherer I Agricultura | Industrial}

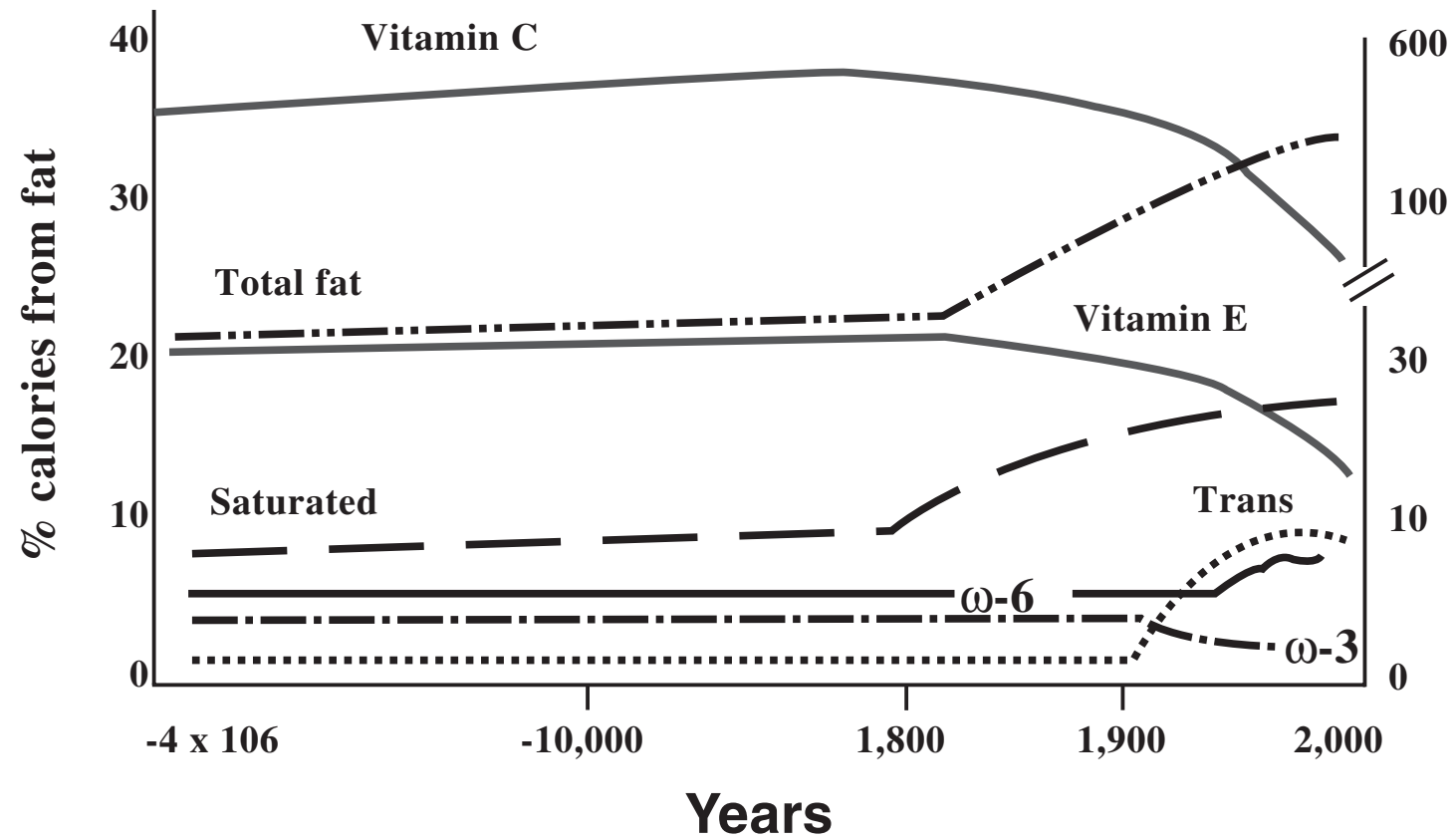

Figure 1. Hypothetical scheme of fat, fatty acid $(\omega-6, \omega-3$, trans and total) intake (as percent of calories from fat) and intake of vitamins $\mathrm{E}$ and $\mathrm{C}(\mathrm{mg} / \mathrm{d})$.

Data were extrapolated from cross-sectional analyses of contemporary hunter-gatherer populations and from longitudinal observations and their putative changes during the preceding 100 years. Trans fatty acids, the result of the hydrogenation process, have increased dramatically in the food supply during this century (46).

TABLE I

Omega-6:omega-3 ratios in various populations

\begin{tabular}{lcc}
\hline \multicolumn{1}{c}{ Population } & omega-6:omega-3 & Reference \\
\hline Paleolithic & 0.79 & 50 \\
Greece prior to 1960 & $1.00-2.0$ & 51 \\
Current US & 16.74 & 50 \\
Current UK and Northern Europe & 15.00 & 52 \\
Current Japan & 4.00 & 53 \\
\hline
\end{tabular}


of long-chain omega-3 PUFAs on various physiologic indexes (7). Whereas the earlier studies were conducted with large doses of fish or fish-oil concentrates, more recent studies have used lower doses (14). ALA, the precursor of omega-3 fatty acids, can be converted to long-chain omega-3 PUFAs and can therefore be substituted for fish oils. The minimum intake of long-chain omega-3 PUFAs needed for beneficial effects depends on the intake of other fatty acids. Dietary amounts of linoleic acid (LA) as well as the ratio of LA to ALA appear to be important for the metabolism of ALA to long-chain omega-3 PUFAs. Indu and Ghafoorunissa (61) showed that while keeping the amount of dietary LA constant, $3.7 \mathrm{~g}$ ALA appears to have biological effects similar to those of $0.3 \mathrm{~g}$ long-chain omega-3 PUFA with conversion of $11 \mathrm{~g}$ ALA to $1 \mathrm{~g}$ long-chain omega-3 PUFA. Thus, a ratio of 4 (15 g LA: $3.7 \mathrm{~g}$ ALA) is appropriate for conversion. This ratio is also consistent with the Lyon Heart Study (12). In human studies, Emken et al. (62) showed that the conversion of deuterated ALA to longer-chain metabolites was reduced by $\sim 50 \%$ when dietary intake of LA was increased from $4.7 \%$ to $9.3 \%$ of energy as a result of the known competition between omega- 6 and omega- 3 fatty acids for desaturation.

Indu and Ghafoorunissa (61) further indicated that increasing dietary ALA increases eicosapentaenoic acid (EPA) concentrations in plasma phospholipids after both 3 and 6 wk of intervention. Dihomo- $\gamma-$ linolenic acid (20:3 $\omega 6)$ concentrations were reduced but arachidonic acid (AA) concentrations were not altered. The reduction in the ratio of long-chain omega- 6 PUFAs to long-chain omega-3 PUFAs was greater after 6 wk than after 3 wk. Indu and Ghafoorunissa were able to show antithrombotic effects by reducing the ratio of omega-6 to omega-3 fatty acids with ALA-rich vegetable oil. After ALA supplementation there was an increase in long-chain omega-3 PUFA in plasma and platelet phospholipids and a decrease in platelet aggregation. ALA supplementation did not alter triacylglycerol concentrations. As shown by others, only omega-3 longchain PUFAs have triacylglycerol-lowering effects (63).
In Australian studies, ventricular fibrillation in rats was reduced with canola oil as much or even more efficiently than with fish oil, an effect attributable to ALA (64). Further studies should be able to show whether this result is a direct effect of ALA per se or occurs as a result of its desaturation and elongation to EPA and docosahexaenoic acid (DHA).

The diets of Western countries have contained increasingly larger amounts of LA, whish has been promoted for its cholesterol-lowering effect. It is now recognized that dietary LA favors oxidative modification of LDL cholesterol $(65,66)$, and increases platelet response to aggregation (67). In contrast, ALA intake is associated with inhibitory effects on the clotting activity of platelets, on their response to thrombin $(68,69)$, and on the regulation of AA metabolism (70). In clinical studies, ALA contributed to lowering of blood pressure (71). In a prospective epidemiological study, Ascherio et al. (72) showed that ALA is inversely related to the risk of coronary heart disease in men.

ALA is not equivalent in its biological effects to the long-chain omega-3 fatty acids found in marine oils. EPA and DHA are more rapidly incorporated into plasma and membrane lipids and produce more rapid effects than does ALA. Relatively large reserves of LA in body fat, as are found in vegans or in the diet of omnivores in Western societies, would tend to slow down the formation of long-chain omega-3 fatty acids from ALA. Therefore, the role of ALA in human nutrition becomes important in terms of long-term dietary intake. One advantage of the consumption of ALA over omega-3 fatty acids from fish is that the problem of insufficient vitamin $\mathrm{E}$ intake does not exist with high intake of ALA from plant sources.

EDIBLE WILD PLANTS AS A SOURCE OF ALPHALINOLENIC ACID

In view of the fact that a number of studies indicate that 18:303 (ALA) is converted to EPA and DHA in human beings, it is 
important to consider terrestrial sources of omega-3 fatty acids in the food supply. ALA, the precursor to EPA and DHA, was first isolated from hempseed oil in 1887 (73). In plants, leaf lipids usually contain large proportions of $18: 3 \omega 3$, which is an important component of chloroplast membrane polar lipids. Mammals who feed on these plants convert $18: 3 \omega 3$ to EPA and DHA, the long-chain omega-3 fatty acids found in fish.

Wild animals and birds who feed on wild plants are very lean with a carcass fat content of only $3.9 \%$ (74) and contain about five times more polyunsaturated fat per gram than is found in domestic livestock $(54,75)$. Most importantly, $4 \%$ of the fat of wild animals contains EPA whereas domestic beef contains very small or undetectable amounts, since cattle are fed grains that are rich in omega- 6 fatty acids and poor in omega-3 fatty acids (76), whereas a deer that forages on ferns and mosses contains omega-3 fatty acids in its meat.

Lipids of liverworts, ferns, mosses and

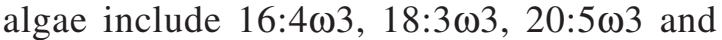
$22: 6 \omega 3$. These are of particular interest because, unlike the higher plants in which $18: 3 \omega 3$ and $16: 3 \omega 3$ are the more abundant, they contain long-chain omega-3 fatty acids such as 20:5 3 (liverwort $=9-11 \%$ ) depending on their state of development. Mosses growing in or near water contain higher percentages of C20 and C22 PUFAs and are morphologically simpler than those that live in dry habitats (77). Thus both the plants, and the animals that feed on them, are good sources of omega-3 fatty acids for human consumption.

In 1984, we initiated a series of studies of the omega-3 fatty acid and antioxidant content of purslane (Portulaca oleracea) and other edible wild plants and compared them to cultivated plants $(47,57,58,78-83)$.

Purslane is one of the plants that was part of the diet of hunter-gatherers in the Pacific Northwest section of the U.S. The large native population encountered at contact (ca. 1790-1850) was nonagricultural and obtained their food by foraging, harvesting and sometimes managing, natural, localized species of plants and animals. In a recent study, Norton et al. studied the vegetable food products of the foraging economies of the Pacific Northwest and found them to be valuable sources of calcium, magnesium, iron, zinc and ascorbic acid (84). Norton states, "These members of the Lily, Purslane, Barberry, Currant, Rose, Parsley, Heath, Honeysuckle, Sunflower and Water-Plantain families are among those regularly collected by these foraging groups whose economic strategies were keyed to the use of multiple resources and the storage of large quantities of processed foods. Stored vegetable foods along with dried fish provide ample and nutritious diets during the seasonal periods of resource non-productivity. Analyses show that these native foods are superior to cultigens in necessary fiber, minerals and vitamins making substantial contributions to pre-contact diets." The results of this study revealed that a wide variety of foods were used to meet nutritional needs and that native preparation and preservation techniques were important factors in retaining nutrients, and in maintaining a balanced diet during seasons of low productivity. The study indicates that vegetable foods were systematically gathered and processed in quantity.

The wide variety of vegetables eaten along the Mediterranean and by foragers contrasts with the relatively narrow variety of crops produced by horticulturists and traditional agriculturists today. Purslane is the eighth most commonly distributed plant in the world. It is eaten both fresh and dry in many parts of the world, including Crete. Table II includes the amount of omega-3 fatty acids in milligrams per gram wet weight of purslane and other commonly eaten leafy vegetables (spinach, buttercrunch lettuce, red leaf lettuce, and mustard greens). As indicated in Table II, purslane contains $8.5 \mathrm{mg}$ of fatty acids per gram of wet weight. In contrast, the other plants are relatively low in lipid content: spinach contains $1.7 \mathrm{mg} / \mathrm{g}$, mustard greens $1.1 \mathrm{mg} / \mathrm{g}$, red leaf lettuce $0.7 \mathrm{mg} / \mathrm{g}$, and buttercrunch lettuce $0.6 \mathrm{mg} / \mathrm{g}$. Purslane, with $4 \mathrm{mg}$ of $18: 3 \omega 3 / \mathrm{g}$ wet weight, is a 
TABLE II

Fatty acid content of plants (mg/g of wet weight)

\begin{tabular}{lccccc}
\hline Fatty acid & Purslane & Spinach & $\begin{array}{c}\text { Buttercrunch } \\
\text { Lettuce }\end{array}$ & $\begin{array}{c}\text { Red Leaf } \\
\text { Lettuce }\end{array}$ & Mustard \\
\hline $14: 0$ & 0.16 & 0.03 & 0.01 & 0.03 & 0.02 \\
$16: 0$ & 0.81 & 0.16 & 0.07 & 0.10 & 0.13 \\
$18: 0$ & 0.20 & 0.01 & 0.02 & 0.01 & 0.02 \\
$18: 1 \omega 9$ & 0.43 & 0.04 & 0.03 & 0.01 & 0.01 \\
$18: 2 \omega 6$ & 0.89 & 0.14 & 0.10 & 0.12 & 0.48 \\
$18: 3 \omega 3$ & 4.05 & 0.89 & 0.26 & 0.31 & 0.00 \\
$20: 5 \omega 3$ & 0.01 & 0.00 & 0.00 & 0.00 & 0.32 \\
$22: 6 \omega 3$ & 0.00 & 0.00 & 0.001 & 0.02 & 1.101 \\
Other & 1.95 & 0.43 & 0.11 & & \\
Total Fatty & & & & & \\
Acid Content & 8.50 & 1.70 & 0.601 & & \\
\hline
\end{tabular}

Modified from reference 57.

good nonaquatic source of 18:3 13 . Based on the information available from the provisional USDA table (85) and our studies $(57,58)$, purslane, a wild growing plant, is the richest source of omega-3 fatty acids of any green leafy vegetable yet examined.

\section{EDIBLE WILD PLANTS AS A SOURCE OF ANTIOXIDANTS}

Consumption of fruits and vegetables has been associated with protection against various diseases, including cardiovascular, cerebro-vascular disease and cancer (2629). It is not known for certain what active dietary constituents contribute to the beneficial effects, but it is often assumed that antioxidant nutrients contribute to this defense. Results from intervention trials on the protective effect of the supplementation with antioxidants such as beta-carotene and vitamin $E$ are not conclusive (39). Therefore, the beneficial effect of a high intake of fruits and vegetables on the risk of cardiovascular disease and cancer may rely not on the effect of the well characterized antioxidants, such as vitamin $\mathrm{E}$ and $\mathrm{C}$ and beta-carotene, but rather on some other antioxidants or non-antioxidant phytochemicals or by an additive action of different compounds present in foods such as alpha-linolenic acid, various phenolic compounds and fiber.

Wild plants are typically known to have higher levels of vitamin $\mathrm{C}$ than cultivated ones (44). Studies from Paleolithic nutrition indicate that the amount of vitamin $\mathrm{C}$ obtained by humans from eating a variety of wild plants was much higher, about 390 $\mathrm{mg} /$ day versus the $88 \mathrm{mg}$ average intake obtained today in the US (44).

We have determined levels of endogenous antioxidants (alpha-tocopherol, ascorbic acid, beta-carotene and glutathione) in plant leaves sampled simultaneously for lipids as previously reported (79). Table III shows the content of alpha-tocopherol, ascorbic acid and betacarotene in chamber-grown purslane, wild purslane and spinach expressed in $\mathrm{mg} / 100 \mathrm{~g}$ fresh weight and in $\mathrm{mg} / 100 \mathrm{~g}$ dry weight. The studies were expanded to include 25 commonly eaten wild plants in Crete. In addition to the vitamin $\mathrm{E}$, total phenols and total antioxidant capacity were determined (81).

\section{Alpha-Tocopherol and Ascorbic Acid}

In a previous survey of the antioxidant content of nine different weed species, it was recorded that levels of alphatocopherol ranged from 10 to $83 \mathrm{mg}$, and levels of ascorbic acid ranged from 2 to 861 mg/100 g dry weight (Table IV) (86). 
TABLE III

Antioxidant content of purslane and spinach leaves

\begin{tabular}{lccc}
\hline & Alpha-Tocopherol & Ascorbic Acid & Beta-Carotene \\
\hline Content, $m g / 100$ g fresh weight & & & \\
Chamber-grown purslane & $12.2 \pm 0.4$ & $26.6 \pm 0.8$ & $1.9 \pm 0.08$ \\
Wild purslane & $8.2 \pm 0.3$ & $23.0 \pm 0.6$ & $2.2 \pm 0.1$ \\
Spinach & $1.8 \pm 0.09$ & $21.7 \pm 0.5$ & $3.3 \pm 0.5$ \\
& & & \\
Content, $m g / 100 \mathrm{~g}$ dry weight & $230 \pm 9$ & $506 \pm 17$ & $38.2 \pm 2.4$ \\
Chamber-grown purslane & $170 \pm 8$ & $451 \pm 14$ & $43.5 \pm 3.0$ \\
Wild purslane & $36 \pm 4$ & $430 \pm 15$ & $63.5 \pm 5.7$ \\
Spinach & & & \\
\hline
\end{tabular}

Data represent mean value from four analyses each with three replicates per species/type.

Reproduced with permission from reference 58.

TABLE IV

Antioxidant content of different plant species ${ }^{1}$

\begin{tabular}{lcc}
\hline \multicolumn{1}{c}{ Plant species } & \multicolumn{2}{c}{ Antioxidants, $\mathrm{mg} / 100 \mathrm{~g}$ dry weight } \\
\cline { 2 - 3 } & Ascorbic acid & Alpha-tocopherol \\
\hline Morning glory & $2 \pm 1$ & $10 \pm 3$ \\
Lamb's quarter & $58 \pm 18$ & $12 \pm 3$ \\
Alfalfa & $143 \pm 12$ & $10 \pm 1$ \\
Pigweed & $504 \pm 24$ & $10 \pm 1$ \\
Buckwheat & $537 \pm 27$ & $28 \pm 2$ \\
Mustard & $469 \pm 24$ & $50 \pm 9$ \\
Sicklepod & $861 \pm 73$ & $60 \pm 6$ \\
Velvetleaf & $92 \pm 7$ & $50 \pm 4$ \\
Jimson weed & $114 \pm 29$ & $83 \pm 16$ \\
\hline
\end{tabular}

${ }^{1}$ Values given for the antioxidants represent the mean \pm SE of 6 plants of each species. Adapted from Table I in reference 86 .

Relative to these findings, and other reports, levels of alpha-tocopherol found in purslane, $230 \pm 9 \mathrm{mg} / 100 \mathrm{~g}$ dry weight, are up to 10 times higher than has been recorded in other weeds (Tables III and IV) (9). Alpha-tocopherol was present in spinach leaves at a level of $30-40 \mathrm{mg} / 100 \mathrm{~g}$ dry weight (Table III). The ascorbic acid content of chamber-grown purslane fell within the range previously reported for other weed species (Table IV) (86), but was significantly higher $(506 \pm 17 \mathrm{mg} / 100 \mathrm{~g}$ dry weight) than the level found in spinach leaves $(430 \pm 5 \mathrm{mg} / 100 \mathrm{~g}$ dry weight) (Table III).

\section{Beta-Carotene}

In photosynthetic tissues of higher plants, beta-carotene and other carotenoids are localized in chloroplasts; while there is little qualitative difference in the pigments present, there is considerable quantitative variation between different species $(87,88)$. The levels of beta-carotene were not significantly different in leaves of chambergrown $(38.2 \pm 2.4 \mathrm{mg} / 100 \mathrm{~g}$ dry weight) compared to wild purslane $(43.5 \pm 3.0 \mathrm{mg} /$ $100 \mathrm{~g}$ dry weight), but these levels were lower than those present in spinach (63.5 \pm $5.7 \mathrm{mg} / 100 \mathrm{~g}$ dry weight) (Table III). 


\section{Glutathione}

The protective role of glutathione as an antioxidant and detoxifying agent has been demonstrated in various clinical studies. It is a ubiquitous compound that is synthesized rapidly in the liver, kidney, and other tissues, including the gastrointestinal tract. In animal cells, glutathione acts as a substrate for glutathione peroxidase, which reduces lipid peroxides that are formed from polyunsaturated fatty acids (PUFA) in the diet, and as a substrate for glutathione-S transferase, which conjugates electrophilic compounds. Recent studies show that glutathione obtained from the diet is directly absorbed by the gastrointestinal tract and thus dietary glutathione can readily increase the antioxidant status in humans (89). Dietary glutathione, in addition to levels supplied by the bile, may be used by the small intestine to decrease the absorption of peroxides. These results indicate that in the intact animal, luminal glutathione is available for use by the intestinal epithelium to metabolize peroxides and other reactive species and to prevent their transport to other tissue.

Dietary glutathione occurs in highest amounts in fresh meats, in moderate amounts in some fruits and vegetables, whereas it is absent or found only in small amounts in grains and dairy products (90). Only fresh asparagus at $28.3 \mathrm{mg} / 100 \mathrm{~g}$ and fresh avocado at $27.7 \mathrm{mg} / 100 \mathrm{~g}$ were higher than purslane in glutathione content in a study carried out to determine the glutathione content of 98 food items, identified by the National Cancer Institute, to contribute $90 \%$ or more of calories, dietary fiber, and 18 major nutrients in the US diet (90-92).

The potential health effects of dietary intake of glutathione in humans are shown in Table V (89,93-101). In a recent study by Flagg et al. (102), plasma glutathione concentrations varied widely in humans and were influenced by sex and age (increased with age in men, but decreased with age and were lower in women who used estrogen-containing contraceptives).

Glutathione is now known to be widely distributed in plant cells and is the major free thiol in many higher plants (103106). Considerable variations in levels of glutathione have been reported by different studies recording thiol levels in a variety of plant species. This may be partially due to the use of different analytical techniques, and because glutathione levels vary both diurnally $(107,108)$ and with developmental and environmental factors (109-111). Taking into account these considerations, the levels of glutathione found in purslane, $14.81 \pm 0.78 \mathrm{mg} / 100 \mathrm{~g}$ fresh weight, were in the range of those reported for other plant species but significantly higher than the level of $9.65 \pm 0.62 \mathrm{mg} / 100 \mathrm{~g}$ fresh

\section{TABLE V}

Potential health effects of dietary glutathione in humans

Glutathione may protect cells from carcinogenic processes through a number of mechanisms:

1. By functioning as an antioxidant $[89,93]$.

2. By binding with mutagenic chemical compounds $[94,95]$.

3. By directly or indirectly acting to maintain functional levels of other antioxidants such as vitamins $\mathrm{C}$ and E and beta-carotene [95-97].

4. Through its involvement in the DNA synthesis and repair $[98,99]$.

5. By enhancing the immune response $[100,101]$. 
weight for spinach (Table VI). Glutathione was present in significantly greater amounts in chamber-grown purslane relative to wild plants, which may have reflected a difference in the developmental stage of the plants analyzed, or in the environmental conditions experienced.
Additional studies were carried out on 25 most commonly eaten wild plants in the Island of Crete (81). Table VII contains the scientific names and the uses of the wild plants of Crete. Table VIII shows the alpha-tocopherol and the total phenols content. Finally, Table IX shows the antioxidant activity and antiradical power of the wild plants (81).

TABLE VI

Glutathione content of purslane and spinach leaves

\begin{tabular}{lccc}
\hline & GSH & GSSX & GSH/GSSX \\
\hline Chamber-grown purslane & $14.81 \pm 0.78(0.48)$ & $2.20 \pm 0.15(0.031)$ & 6.73 \\
Wild purslane & $11.90 \pm 0.63(0.39)$ & $1.42 \pm 0.12(0.023)$ & 8.38 \\
Spinach & $9.65 \pm 0.62(0.31)$ & $2.39 \pm 0.20(0.039)$ & 4.03 \\
\hline
\end{tabular}

Data represent mean values (mg/100 g fresh weight) from four analyses each with three replicates per plant species/type. Figures in parentheses are values expressed as $\mu \mathrm{mol} / \mathrm{g}$ fresh weight to allow comparison with data previously reported in the literature. GSH = glutathione; GSSX = glutathione-linked disulfides.

Reproduced with permission from reference 58.

TABLE VII

The scientific names and the uses of the Cretan wild plants

\begin{tabular}{lll}
\hline No & \multicolumn{1}{c}{ PLANTS NAMES } & \multicolumn{1}{c}{ USES } \\
\hline 1 & Papaver rhoeas & Cooked with olive oil, vegetable pie \\
2 & Sonchus Oleraceus & Boiled salad, Cooked with olive oil, vegetable pie, raw salad \\
3 & Pimpinela peregrina & Cooked with oil, vegetable pie \\
4 & Centaurea idaea & Boiled salad \\
5 & Tragopogon Sinuatus & Cooked with olive oil, vegetable pie \\
6 & Crepis Commutata & Boiled salad \\
7 & Helmintotheca echioides & Boiled salad \\
8 & Tordylium apulum & Cooked with oil, vegetable pie \\
9 & Scandix pecten-veneris & Cooked with olive oil, vegetable pie \\
10 & Pontikes & Cooked with olive oil, vegetable pie, raw salad \\
11 & Allium subhirstum & Cooked with olive oil, vegetable pie \\
12 & Rumex ssp. & Cooked with olive oil, vegetable pie \\
13 & Silene Vulgaris & Cooked with olive oil, vegetable pie \\
14 & Crepis vesicaria & Boiled salad \\
15 & Uropermun picroides & Boiled salad \\
16 & Tolpis virgata & Cooked with olive oil, vegetable pie, Boiled salad \\
17 & Hypochoeris radicata & Boiled salad \\
18 & Cichorium pumilum & Boiled salad \\
19 & Oebothera pimpineloides & Cooked with olive oil, vegetable pie \\
20 & Leontodon tuberosus & Cooked with olive oil, vegetable pie \\
21 & Cichorium spinosum & Boiled salad, raw salad \\
22 & Ranunculus ficarioides & Cooked with olive oil, vegetable pie, Boiled salad, raw salad \\
23 & Prasium majus & Cooked with olive oil, vegetable pie \\
24 & Foeniculum vulgare ssp.piperitum & Cooked with olive oil, vegetable pie \\
25 & Stypocaulon scoparium & Raw salad \\
\hline & &
\end{tabular}

* Both raw and boiled salads are dressed with olive and lemon or vinegar.

Reproduced with permission from reference 81 . 
TABLE VIII

$\alpha$-Tocopherol and Total Phenols content of Cretan edible wild plants

\begin{tabular}{|c|c|c|c|}
\hline $\mathrm{N}^{\circ}$ & Plant Names & $\begin{array}{c}\alpha \text {-tocopherol } \\
\text { (mg/100g wet weight) }\end{array}$ & $\begin{array}{c}\text { Total phenols } \\
\text { (mg/100g wet weight) }\end{array}$ \\
\hline 1 & Papaver rhoeas & 0.524 & $33.5 \pm 0.81$ \\
\hline 2 & Sonchus oleraceus & 0.294 & $48.04 \pm 0.79$ \\
\hline 3 & Pimpinela peregrina & 0.490 & $47.65 \pm 0.33$ \\
\hline 4 & Centaurea idaea & 0.108 & $61.55 \pm 1.45$ \\
\hline 5 & Tragopogon Sinuatus & 0.206 & $20.82 \pm 0.14$ \\
\hline 6 & Crepis Commutata & 0.360 & $49.08 \pm 2.32$ \\
\hline 7 & Helmintotheca echioides & 0.029 & $44.86 \pm 1.08$ \\
\hline 8 & Tordylium apulum & 2.426 & $46.87 \pm 1.25$ \\
\hline 9 & Scandix pecten-veneris & 1.133 & $46.51 \pm 1.13$ \\
\hline 10 & Pontikes & 0.360 & $59.27 \pm 1.10$ \\
\hline 11 & Allium subhirstum & 1.215 & $14.54 \pm 0.65$ \\
\hline 12 & Rumex ssp. & 0.509 & $102.56 \pm 3.13$ \\
\hline 13 & Silene Vulgaris & 0.354 & $40.18 \pm 1.20$ \\
\hline 14 & Crepis vesicaria & 0.401 & $49.42 \pm 2.87$ \\
\hline 15 & Uropermum picroides & 0.482 & $35.76 \pm 0.54$ \\
\hline 16 & Tolpis virgata & 0.043 & $21.46 \pm 0.47$ \\
\hline 17 & Hypochoeris radicata & 0.193 & $57.03 \pm 0.32$ \\
\hline 18 & Cichorium pumilum & 0.420 & $93.64 \pm 0.28$ \\
\hline 19 & Oenothera pimpineloides & 0.232 & $55.05 \pm 1.31$ \\
\hline 20 & Leontodon tuberosus & 0.099 & $48.06 \pm 0.39$ \\
\hline 21 & Cichorium spinosum & 0.398 & $72.63 \pm 0.37$ \\
\hline 22 & Ranunculus ficarioides & 0.443 & $32.99 \pm 0.60$ \\
\hline 23 & Prasium majus & 1.287 & $78.72 \pm 0.44$ \\
\hline 24 & Foeniculum vulgare ssp.piperitum & 1.117 & $82.521 \pm 0.60$ \\
\hline 25 & Stypocaulon scoparium & 0.000 & $6.736 \pm 0.52$ \\
\hline
\end{tabular}

Reproduced with permission from reference 81 .

TABLE IX

Antioxidant Activity and Antiradical Power of Cretan edible wild plants.

\begin{tabular}{llcc}
\hline $\mathrm{N}^{\circ}$ & \multicolumn{1}{c}{ Plant Names } & $\begin{array}{c}\text { Antioxidant Activity(EC50) } \\
\text { (mg dry extract/mg DPPH) }\end{array}$ & $\begin{array}{c}\text { ARP } \\
(1 / \mathrm{EC} 50)\end{array}$ \\
\hline 1 & Papaver rhoeas & $0,995 \pm 0.14$ & $1,005 \pm 0.15$ \\
2 & Sonchus oleraceus & $3,664 \pm 0.05$ & $0,273 \pm 0.004$ \\
3 & Pimpinela peregrina & $2,909 \pm 0.29$ & $0,346 \pm 0.036$ \\
4 & Centaurea idaea & $1,400 \pm 0.011$ & $0,714 \pm 0.005$ \\
5 & Tragopogon Sinuatus & $3,679 \pm 0.16$ & $0,272 \pm 0.012$ \\
6 & Crepis Commutata & $3,169 \pm 0.14$ & $0,316 \pm 0.014$ \\
7 & Helmintotheca echioides & $2,344 \pm 0.17$ & $0,428 \pm 0.031$ \\
8 & Tordylium apulum & $2,852 \pm 0.13$ & $0,351 \pm 0.017$ \\
9 & Scandix pecten-veneris & $2,477 \pm 0.11$ & $0,404 \pm 0.018$ \\
10 & Pontikes & $7,261 \pm 0.25$ & $0,138 \pm 0.005$ \\
11 & Allium subhirstum & $2,697 \pm 0.08$ & $0,371 \pm 0.01$ \\
12 & Rumex ssp. & $2,344 \pm 0.17$ & $0,428 \pm 0.03$ \\
13 & Silene Vulgaris & $2,852 \pm 0.13$ & $0,351 \pm 0.02$ \\
14 & Crepis vesicaria & $2,284 \pm 0.42$ & $0,438 \pm 0.09$ \\
15 & Uropermum picroides & $0,830 \pm 0.20$ & $1,205 \pm 0.37$ \\
16 & Tolpis virgata & $1,350 \pm 0.12$ & $0,741 \pm 0.06$ \\
17 & Hypochoeris radicata & $0,761 \pm 0.22$ & $1,390 \pm 0.45$ \\
18 & Cichorium pumilum & $0,696 \pm 0.55$ & $2,039 \pm 1.18$ \\
19 & Oenothera pimpineloides & $0,222 \pm 0.018$ & $4,520 \pm 0.35$ \\
20 & Leontodon tuberosus & $1,194 \pm 0.047$ & $0,838 \pm 0.03$ \\
21 & Cichorium spinosum & $1,115 \pm 0.28$ & $0,944 \pm 0.28$ \\
22 & Ranunculus ficarioides & $0,280 \pm 0.08$ & $3,812 \pm 1.27$ \\
23 & Prasium majus & $0,818 \pm 0.27$ & $1,321 \pm 0.46$ \\
24 & Foeniculum vulgare ssp.piperitum & $1,041 \pm 0.15$ & $0,974 \pm 0.14$ \\
25 & Stypocaulon scoparium & $2,367 \pm 0.19$ & $0,424 \pm 0.035$ \\
\hline
\end{tabular}

Reproduced with permission from reference 81 . 


\section{Phenols}

Flavonoids and other phenolic compounds are antioxidants that contribute to the high antioxidant capacity observed in certain fruits and vegetables. There are several thousand different flavonoids present in plants, and many of them have antioxidant activities (112). The antioxidant capacities, measured as oxygen radical absorbance assay (ORAC) of some flavonoids were found to be several times stronger on the basis of molar concentration than vitamins $\mathrm{E}$ and $\mathrm{C}$ (112). Such phenolic compounds have already been implicated as playing a role in the protection that fruits and vegetables have against chronic diseases (112). However, the extent to which these potentially important antioxidants can be absorbed is not clear, although early evidence indicates that substantial quantities of the flavonoids are absorbed.

\section{Antioxidant Capacity}

Various methods have been developed to measure total antioxidant capacity or activity, such as the ORAC (43), or the 2,2diphenyl-1-picrylhydrazyl (DPPH') (113) free radical assay which measures the antiradical power (ARP): the higher the ARP, the more efficient the antioxidant. In general, more than $80 \%$ of the total antioxidant capacity in fruits and vegetables comes from ingredients other than vitamin $C$, indicating the presence of other potentially important antioxidants in these foods (43). ORAC varies considerably (2030 fold) from one kind of fruit or vegetable to another. As expected, the majority of studies have been carried out in cultivated fruits and vegetables. Brussel sprouts are one of the vegetables that show high ORAC activity. Garlic, kale, and spinach are particularly high, as are strawberries and plums.

In a recent paper on the systematic screening of total antioxidants in dietary plants, using the ferric-reducing ability of plasma (FRAP) method (43), Halvorsen et al. (114) emphasized the need for a systematic analysis in order to facilitate research into the nutritional role of a combined effect of antioxidants in dietary plants.

\section{CONCLUSIONS}

Current research clearly shows that human beings evolved on a diet that was based on wild plants, particularly green leafy vegetables, meat from animals in the wild, and fish from rivers, lakes and deep cold sea water. This diet provided equal amounts of omega-6 and omega-3 essential fatty acids. Furthermore, the diet contained omega-3 fatty acids from terrestrial sources (predominately ALA) and high amounts of EPA and DHA from both animals and fish. The green leafy vegetables provided antioxidant vitamins, minerals, and various phytochemicals with antioxidant properties.

Studies on wild plants relative to the omega-3 fatty acids and antioxidant content are being carried out in various parts of the world. As expected, they show enormous variation in the content of both omega-3 fatty acids and antioxidants due to variation in climatic conditions and cultivars. In developing new sources of food, the study of the dietary composition of wild plants is essential. Their cultivation should lead to increased production of plants rich in omega- 3 fatty acids and antioxidants, both of which reduce the risk of chronic diseases.

\section{REFERENCES}

1. SIMOPOULOS AP (1991) Omega-3 fatty acids in health and disease and in growth and development. Am J Clin Nutr 54: 438-463

2. SIMOPOULOS AP (1986) Kifer RR, Martin RE (eds). Health Effects of Polyunsaturated Fatty Acids in Seafoods. Orlando, FL, Academic Press.

3. GALLI C, SIMOPOULOS AP (eds) (1989) Dietary $\omega 3$ and $\omega 6$ Fatty Acids. Biological Effects and Nutritional Essentiality. New York, Plenum Press

4. SIMOPOULOS AP, KIFER RR, MARTIN RE, BARLOW SM (eds) (1991). Health Effects of $\omega 3$ Polyunsaturated Fatty Acids in Seafoods. World Rev Nutr Diet 66: 1-592

5. GALLI C, SIMOPOULOS AP, TREMOLI E (eds) (1994) Fatty Acids and Lipids: Biological Aspects. World Rev Nutr Diet 75: 1-197

6. GALli C, SIMOPOULOS AP, TREMOLI E (eds) (1994) Effects of Fatty Acids and Lipids in Health and Disease. World Rev Nutr Diet 76: 1-152

7. SALEM N JR, SIMOPOULOS AP, GALLI C, LAGARDE M, KNAPP HR (eds) (1996) Fatty Acids and Lipids from Cell Biology to Human Disease. Lipids 31(suppl): S1-S326

8. SIMOPOULOS AP (1997) W-3 fatty acids in the prevention-management of cardiovascular disease. Can J Physiol Pharmacol 75: 234-239 
9. LAGARDE M, SPECTOR AA, GALLI C, HAMAZAKI T, KNAPP HR (eds) (1999) Fatty Acids and Lipids from Cell Biology to Human Disease. Lipids 34(suppl): S1-S350

10. HAMAZAKI T, OKUYAMA H (2001) Fatty Acids and Lipids - New Findings. World Rev Nutr Diet 88: 1-260

11. BURR ML, FEHILY AM, GILBERT JF, ROGERS S, HOLLIDAY RM, SWEETNAM PM, ELWOOD PC, DEADMAN NM (1989) Effect of changes in fat, fish and fibre intakes on death and myocardial reinfarction: diet and reinfarction trial (DART). Lancet 2: 757-761

12. DE LORGERIL M, RENAUD S, MAMELLE N SALEN P, MARTIN JL, MONJAUD I, GUIDOLLET J, TOUBOUL P, DELAYE J (1994) Mediterranean alinolenic acid-rich diet in secondary prevention of coronary heart disease. Lancet 343: 1454-1459

13. SINGH RB, NIAZ MA, SHARMA JP, KUMAR R, RASTOGI V, MOSHIRI M (1997) Randomized, double-blind, placebo-controlled trial of fish oil and mustard oil in patients with suspected acture myocardial infarction. The Indian experiment of infarct survival-4. Cardiovasc Drugs Ther 11: 485-491

14. GISSI-Prevenzione Investigators (1999) Dietary supplementation with $\mathrm{n}-3$ polyunsaturated fatty acids and vitamin $\mathrm{E}$ after myocardial infarction: results of the GISSI-Prevenzione trial. Lancet 354: 447-455

15. MORRIS MC, SACKS F, ROSNER B (1994) Fish oil to reduce blood pressure: a meta-analysis. Ann Intern Med 120(suppl): 10

16. APPEL LJ, MILLER ER, SEIDLER AJ, WHELTON PK (1994) Diet supplementation with fish oils and blood pressure reduction: a meta-analysis. Ann Intern Med 120(suppl): 10

17. APPEL LJ, MILLER ER $3^{\text {rd }}$, SEIDLER AJ, WHELTON PK (1993) Does supplementation of diet with "fish oil" reduce blood pressure? A meta-analysis of controlled clinical trials. Arch Intern Med 153: 1429-1438

18. RAHEJA BS, SADIKOT SM, PHATAK RB, RAO MB (1993) Significance of the $n-6 / n-3$ ratio for insulin action in diabetes. Ann N Y Acad Sci 683: 258-271

19. CONNOR WE, PRINCE MJ, ULLMANN D, et al. (1993) The hypotriglyceridemic effect of fish oil in adult-onset diabetes without adverse glucose control. Ann N Y Acad Sci 683: 337-340

20. DE CATERINA R, CAPRIOLI R, GIANNESSI D, SICARI R, GALLI C, LAZZERINI G, BERNINI W, CARR L, RINDI P (1993) n-3 fatty acids reduce proteinuria in patients with chronic glomerular disease. Kidney Int 44: 843-850

21. DONADIO JV JR, BERGSTRALH EJ, OFFORD KP, SPENCER DC, HOLLEY KE (1994) A controlled trial of fish oil in IgA nephropathy. Mayo Neprology Collaborative Group. N Engl J Med 331: 1194-1199

22. KREMER JM (1996) Effects of modulation of inflammatory and immune parameters in patients with rheumatic and inflammatory disease receiving dietary supplementation of n-3 and n-6 fatty acids. Lipids 31(suppl): S243-S247

23. STENSON WF, CORT D, RODGERS J, BURAKOFF $\mathrm{R}$, DESCHRYVER-KECSKEMETI K, GRAMLICH TL, BEEKEN W (1992) Dietary supplementation with fish oil in ulcerative colitis. Ann Intern Med 116: 609614

24. BELLUZZI A, BRIGNOLA C, CAMPIERI M, PERA A, BORSCHI S, MIGLIOLI M (1996) Effect of an enteric-coated fish-oil preparation on relapses in Crohn's disease. N Engl J Med 1334: 1557-1560

25. SHAHAR E, FOLSOM AR, MELNICK SL, TOCKMAN MS, COMSTOCK GW, GENNARO V,
HIGGINS MW, SORLIE PD, KO WJ, SZKLO M (1994) Dietary n-3 polyunsaturated fatty acids and smoking-related chronic obstructive pulmonary disease. Atherosclerosis Risk in Communities Study Investigators. New Engl J Med 331: 228-233

26. AMES BM (1983) Dietary carcinogens and degenerative diseases. Science 221: 1256-1263

27. GEY KF (1990) The antioxidant hypothesis of cardiovascular disease: epidemiology and mechanisms. Biochem Soc Trans 18: 1041-1045

28. STEINBERG D (1991) Antioxidants and atherosclerosis: a current assessment. Circulation 84: 1420-1425

29. STEINBERG D, PARTHASARATHY S, CAREW TE, KHOO JC, WITZTUM JL (1989) Beyond cholesterol: modifications of low-density lipoprotein that increase its atherogenicity. New Engl J Med 320: 915-924

30. GUTTERIDGE JM, HALLIWELL B (2000) Free radicals and antioxidants in the year 2000: a historical look to the future. Ann NY Acad Sci 899: 136-147

31. HALLIWELL B (1999) Antioxidant defence mechanisms: from the beginning to the end (of the beginning). Free Radic Res 31: 261-272

32. CARR A, FREI B (1999) Does vitamin C act as a pro-oxidant under physiological conditions? FASEB J 13: $1007-1024$

33. SIES H, STAHL W (1995) Vitamin E and C, $\beta$-carotene, and other carotenoids as antioxidants. Am J Clin Nutr 62: 1315S-1321S

34. PACKER L, WEBER SU, RIMBACH G (2001) Molecular aspects of $\alpha$-tocotrienol antioxidant action and cell signalling. J Nutr 131: 369S-373S

35. HALLIWELL B (2000) The antioxidant paradox. Lancet 355: 1179-1180

36. McCALL MR, FREI B (1999) Can antioxidant vitamins materially reduce oxidative damage in humans? Free Radic Biol Med 26: 1034-1053

37. ALBANES D, HEINONEN OP, TAYLOR PR, VIRTAMO J, EDWARDS BK, RAUTALAHTI M, HARTMAN AM, PAIMGREN J, FREEDMAN LS, HAAPAKOSKI J, BARRETT MJ, PIETINEN P, MALILA N, TALA E, LIIPPO K, SALOMAA ER, TANGREA JA, TEPPO L, ASKIN FB, TASKINEN E, EROZAN Y, GREENWALD P, HUTTUNEN JK (1996) $\alpha$-Tocopherol and $\beta$-carotene supplements and lung cancer incidence in the $\alpha$-tocopherol, $\beta$-carotene cancer prevention study: effects of base-line characteristics and study compliance. J Natl Cancer Inst 88: 1560-1570

38. OMENN GS, GOODMAN GE, THORNQUIST MD, BALMES J, CULLEN MR, GLASS A, KEOGH JP, MAYSKENS FL, VALANIS B, WILLIAMS JH, BARNHART S, CHERNIACK MG, BRODKIN CA, HAMMAR S (1996) Risk factors for lung cancer and for intervention effects in CARET, the $\beta$-Carotene and Retinol Efficacy Trial. J Natl Cancer Inst 88: 1550-1559

39. OMENN GS, GOODMAN GE, THORNQUIST MD, BALMES J, CULLEN MR, GLASS A, KEOGH JP, MEYSKENS FL, VALANIS B, WILLIAMS JH, BARNHART S, HAMMAR S (1996) Effects of a combination of $\beta$-carotene and vitamin $A$ on lung cancer and cardiovascular disease. N Engl J Med 334: 1150-1155

40. RAPOLA JM, VIRTAMO J, RIPATTI S, HUTTUNEN JK, ALBANES D, TAYLOR PR, HEINONEN OP (1997) Randomised trial of $\alpha$-tocopherol and $\beta$ carotene supplements on incidence of major coronary events in men with previous myocardial infarction. Lancet 349: 1715-1720

41. MiLleR NJ, RICE-EVANS CA (1996) Spectrophotometric determination of antixodant activity. Redox Rep 12: 161-168 
42. BENZIE IFF, STRAIN JJ (1996) The ferric reducing ability of plasma (FRAP) as a measure of "antioxidant power": the FRAP assay. Anal Biochem 239: 70-76

43. CAO G, ALESSIO HM, CUTLER RG (1993) Oxygenradical absorbance capacity assay for antioxidants. Free Radic Biol Med 14: 303-311

44. EATON SB, KONNER M (1985) Paleolithic nutrition. A consideration of its nature and current implications. N Engl J Med 312: 283-289

45. SIMOPOULOS AP (1995) Evolutionary aspects of diet: fatty acids, insulin resistance and obesity. In: VanItallie TB, Simopoulos AP (eds). Obesity: New Directions in Assessment and Management. Philadelphia, Charles Press, 241-261

46. SIMOPOULOS AP (1999) Genetic variation and evolutionary aspects of diet. In: Papas AM (ed). Antioxidant Status, Diet, Nutrition and Health. Boca Raton, CRC Press, 65-88

47. SIMOPOULOS AP (ed) (1995) Plants in Human Nutrition. World Rev Nutr Diet. Basel, Karger, vol. 77

48. Report of the National Cholesterol Education Program Expert Panel on detection, evaluation and treatment of high blood cholesterol in adults (1988) Arch Intern Med 148: 36-69

49. SIMOPOULOS AP (2001) Evolutionary aspects of diet and essential fatty acids. In: Hamazaki T, Okuyama $\mathrm{H}$ (eds). Fatty Acids and Lipids - New Findings. World Rev Nutr Diet 88: 18-27

50. EATON SB, EATON SB III, SINCLAIR AJ, CORDAIN L, MANN NJ (1998) Dietary intake of long-chain polyunsaturated fatty acids during the Paleolithic. In: Simopoulos AP (ed). The Return of $\omega 3$ Fatty Acids into the Food Supply: I. Land-Based Animal Food Products and Their Health Effects. World Rev Nutr Diet. 83: 12-23

51. SIMOPOULOS AP (1998) Overview of evolutionary aspects of $\omega 3$ fatty acids in the diet. In: Simopoulos AP (ed). The Return of $\omega 3$ Fatty Acids into the Food Supply: I. Land-Based Animal Food Products and Their Health Effects. World Rev Nutr Diet. 83: 1-11

52. SANDERS TAB (2000) Polyunsaturated fatty acids in the food chain in Europe. Am J Clin Nutr 71(suppl): S176-S178

53. SUGANO M, HIRAHARA F (2000) Polyunsaturated fatty acids in the food chain in Japan. Am J Clin Nutr 71(suppl): S189-S196

54. CRAWFORD MA (1968) Fatty acids in free-living and domestic animals. Lancet 1: 1329-1333

55. VAN VLIET T, KATAN MB (1990) Lower ratio of n-3 to $\mathrm{n}-6$ fatty acids in cultured than in wild fish. Am J Clin Nutr 51: 1-2

56. SIMOPOULOS AP, SALEM N JR (1989) n-3 fatty acids in eggs from range-fed Greek chickens. N Engl J Med 321: 1412

57. SIMOPOULOS AP, SALEM N JR (1986) Purslane: a terrestrial source of omega-3 fatty acids. N Engl J Med 315: 833 (letter)

58. SIMOPOULOS AP, NORMAN HA, GILLASPY JE (1995) Purslane in human nutrition and its potential for world agriculture. World Rev Nutr Diet 77: 47-74

59. SIMOPOULOS AP, LEAF A, SALEM N JR (1999) Essentiality of and recommended dietary intakes for omega-6 and omega-3 fatty acids. Ann Nutr Metab 43: 127-130

60. CRAWFORD M, GALLI C, VISIOLI F, RENAUD S, SIMOPOULOS AP, SPECTOR AA (2000) Role of plant-derived omega-3 fatty acids in human nutrition. Ann Nutr Metab. 44: 263-265

61. INDU M, GHAFOORUNISSA (1992) n-3 fatty acids in Indian diets - comparison of the effects of precursor (alpha-linolenic acid) vs product (long chain n-3 polyunsaturated fatty acids). Nutr Res 12: 569-582

62. EMKEN EA, ADLOT RO, GULLEY RM (1994) Dietary linoleic acid influences desaturation and acylation of deuterium-labeled linoleic and linolenic acids in young adult males. Biochem Biophys Acta 1213: $277-288$

63. MANTZIORIS E, JAMES MJ, GIBSON RA, CLELAND LG (1994) Dietary substitution with an alinolenic acid-rich vegetable oil increases eicosapentaenoic acid concentrations in tissues. Am J Clin Nutr 59: 1304-1309

64. McLENNAN PL (1993) Relative effects of dietary saturated, monounsaturated, and polyunsaturated fatty acids on cardiac arrhythmias in rats. Am J Clin Nutr 57: 207-212

65. REAVEN P, PARTHASARATHY S, GRASSE BJ, MILLER E, ALMAZAN F, MATTSON FH, KHOO JC, STEINBERG D, WITZTUM JL (1991) Feasibility of using an oleate-rich diet to reduce the susceptibility of low-density lipoprotein to oxidative modification in humans. Am J Clin Nutr 54: 701-706

66. ABBEY M, BELLING GB, NOAKES M, HIRATA F, NESTEL PJ (1993) Oxidation of low-density lipoproteins: intraindividual variability and the effect of dietary linoleate supplementation. Am J Clin Nutr 57: 391-398

67. RENAUD S (1990) Linoleic acid, platelet aggregation and myocardial infarction. Atherosclerosis 80: 255-256

68. RENAUD S, MORAZAIN R, GODSEY F, DUMONT E, THEVENON C, MARTIN JL, MENDY F (1986) Nutrients, platelet function and composition in nine groups of French and British farmers. Atherosclerosis 60: $37-48$

69. RENAUD S, GODSEY F, DUMONT E, THEVENON C, ORTCHANIAN E, MARTIN JL (1986) Influence of long-term diet modification on platelet function and composition in Moselle farmers. Am J Clin Nutr 43: 136- 150

70. BUDOWSKI P, CRAWFORD MA (1985) Alphalinolenic acid as a regulator of the metabolism of arachidonic acid: dietary implications of the ratio of $n-$ 6: n-3 fatty acids. Proc Nutr Soc 44: 221-229

71. BERRY EM, HIRSCH J (1986) Does dietary linoleic acid influence blood pressure? Am J Clin Nutr 44: 336340

72. ASCHERIO A, RIMM EB, GIOVANNUCCI EL, SPIEGELMAN D, STAMPFER M, WILLETT WC (1996) Dietary fat and risk of coronary heart disease in men: cohort follow up study in the United States. BMJ 313: 84-90

73. DEUEL HJ, JR (1951) The Lipids, Vol. 1. Interscience Publishers, Inc.: New York, p. 18

74. LEDGER HP (1968) Body composition as a basis for a comparative study of some East African mammals. Symp Zool Soc London 21: 289-310

75. WO CKW, DRAPER HH (1975) Vitamin E status of Alaskan Eskimos. Am J Clin Nutr 28: 808-813

76. CRAWFORD MA, GALE MM, WOODFORD MH (1969) Linoleic acid and linolenic acid elongation products in muscle tissue of Syncerus caffer and other ruminant species. Biochem J 115: 25-27

77. TINOCO J (1987) Dietary requirements and functions of alpha-linolenic acid in animals. Prog Lipid Res 21: 1-45

78. SIMOPOULOS AP (1988) Terrestrial sources of omega-3 fatty acids: purslane. In: Quebedeaux B, Bliss FA (eds). Horticulture and Human Health. Contributions of Fruits and Vegetables. Prentice Hall, Englewood Cliffs, NJ pp. 93-107 
79. SIMOPOULOS, AP, NORMAN HA, GILLASPY JE, DUKE JA (1992) Common purslane: a source of omega-3 fatty acids and antioxidants. J Am College Nutr 11: 374-382

80. ZEGHICHI S, KALLITHRAKA S, SIMOPOULOS AP (2000) Antioxidant content and fatty acid composition of Corchorus olitorius and Cichorium spinosum. Program and Abstract Book. Fourth International Conference on Nutrition and Fitness, Ancient Olympia, Greece, May Pp. 103-104

81. ZEGHICHI S, KALLITHRAKA S, SIMOPOULOS AP, KYPRIOTAKIS Z (2003) The nutritional composition of selected wild plants in the diet of Crete. In: Simopoulos AP, Gopalan C (eds). Plants in Human Health and Nutrition Policy. World Rev Nutr Diet. Karger, Basel, 91: 22-40

82. ZEGHICHI S, KALLITHRAKA S, SIMOPOULOS AP (2003) Nutritional composition of Molokhia (Corchorus olitorius) and Stamnagathi (Cichoium spinosum). In: Simopoulos AP, Gopalan C (eds). Plants in Human Health and Nutrition Policy. World Rev Nutr Diet. Karger, Basel, 91: 1-21

83. SIMOPOULOS AP, GOPALAN C (eds) Plants in Human Health and Nutrition Policy. World Rev Nutr Diet. Karger, Basel, vol. 91

84. NORTON HH, HUNN ES, MARTINSEN CS, KEELY PB (1984) Vegetable food products of the foraging economies of the Pacific Northwest. Ecol Food \& Nutr 14: $219-228$

85. UNITED STATES DEPARTMENT OF AGRICULTURE (1986) Provisional table on the content of omega-3 fatty acids and other fat components in selected foods. In: Simopoulos AP, Kifer RR, Martin RE (eds). Health Effects of Polyunsaturated Fatty Acids in Seafoods. Orlando, FL, Academic Press

86. FINCKH BF, KUNERT KJ (1985) Vitamin C and E: An antioxidative system against herbicide-induced lipid peroxidation in higher plants. J Agri Food Chem 33: $574-577$

87. SPURGEON SLl, PORTER JW (1980) Carotenoids. In: Stumpf PK (ed). The Biochemistry of Plants, Lipids: Structure and Function. New York, Academic Press, vol. 40, pp 419-483

88. GOODWIN TW (1976) Distribution of carotenoids. In Goodwin TW (ed): Chemistry and Biochemistry of Plant Pigments. New York, Academic Press, vol. 1, pp. 127-142

89. JONES DP, HAGEN TM, WEBER R, WIERZBICKA GT, BONKOVSKY HL (1989) Oral administration of glutathione (GSH) increases plasma GSH concentrations in humans (abstract). FASEB J 3: A 1250

90. JONES DP, COATES RJ, FLAGG EW, et al. (1992) Glutathione in Foods listed in the National Cancer Institute's Health Habits and History Food Frequency Questionnaire. Nutr Cancer 17: 57-75

91. BLOCK G, DRESSER CM, HARTMAN AM, CARROLL MD (1985) Nutrient sources in the American diet: Quantitative data from the NHANES II Survey. I. Vitamins and Minerals. Am J Epidemiol 122: $13-26$

92. BLOCK G, DRESSER CM, HARTMAN AM, CARROLL MD (1985) Nutrient sources in the American diet: Quantitative data from the NHANES II Survey. Macronutrients and Fats. Am J Epidemiol 122: $27-40$

93. MANNERVIK B, CARLBERG I, LARSON K (1989) Glutathione: General review of mechanisms of action. In Dolphin D, Avramovic O, Pulson R (eds). Glutathione. Chemical, Biochemical and Medical Aspects. New York, Wiley, pt. A, pp 475516

94. WATTENBERG LW (1985) Perspectives in cancer research. Chemoprevention of cancer. Cancer Res 45: $1-8$

95. FREI B, ENGLAND L, AMES BN (1989) Ascorbate is an outstanding antioxidant in human blood plasma. Proc Natl Acad Sci USA 86: 6377-6381

96. BENDICH A (1985) Antioxidant micronutrients in immune responses. In: Bendich A, Chandra RK (eds). Micronutrients and Immune Functions. New York, New York Academy of Sciences, vol. 587, pp 169-180

97. FREI B, STOCKER R, AMES BN (1988) Antioxidant defenses and lipid peroxidation in human blood. Proc Natl Acad Sci USA 85: 9748-9752

98. OLEINICK NL, XUE L, FRIEDMAN LR, DONAHUE LL, BIAGLOW JE (1988) Inhibition of radiationinduced DNA-protein cross-link repair by glutathione depletion with L-buthionine sulfoximine. NCI Monogr 6: 225-229

99. FUCHS JA (1989) Glutaredoxin. In: Dolphin D, Avramovic O, Poulson R (eds). Glutathione. Biochemical and Medical Aspects. New York, Wiley, pt B, pp 551-570

100. FURUKAWA T, MEYDANI SN, BLUMBERG JB (1987) Reversal of age-associated decline in immune responsiveness by dietary glutathione supplementation in mice. Mech Ageing Dev 38: 107-117

101.BUHL R, HOLROYD KJ, MASTRANGELI A, CANTIN AM, JAFFE HA, et al. (1989) Systematic glutathione deficiency in symptom-free HIVseropositive individuals. Lancet ii: 1294-1298

102. FLAGG EW, COATES RJ, JONES DP, ELEY JW, GUNTER EW, JACKSON B, GREENBERG RS (1993) Plasma total glutathione in humans and its association with demographic and health-related factors. Br J Nutr 70: 797-808

103. McCAY PB (1985) Vitamin E. Interactions with free radicals and ascorbate. Ann Rev Nutr 5: 323-340

104. RENNEBERG H (1982) Glutathione metabolism and possible biological roles in the higher plant. Phytochemistry 21: 2771-2781

105. RENNEBERG H (1987) Aspects of glutathione function and metabolism in plants. In: Von Wettstein D, Chua NH (eds). Plant Molecular Biology. New York, Plenum Press, pp 279-292

106. HATZIOS KK, BORMANN JF (eds) (1989) Proceedings 1989 Annual Symposium South ASPP. Glutathione Synthesis and Function in Higher Plants. Physiol Plant 77: 447-471

107. KOIKE S, PATTERSON BD (1988) Diurnal variation of glutathione levels in tomato seedlings. Hort Sci 23: 713-714

108. SCHUPP R, RENNENBERG H (1988) Diurnal changes in the glutathione content of spruce needles (Picea abies L.) Plant Sci 57: 113-117

109. EARNSHAW BA, JOHNSON MA (1987) Control of wild carrot somatic embryo development by antioxidants. Plant Physiol 85: 273-276

110. DE KOK LJ, DE KAN PJL, TANCZOS OG, KUIPER PJC (1981) Sulphate-induced accumulation of glutathione and frost-tolerance of spinach leaf tissue. Physiol Plant 53: 435-438

111. WISE RR, NAYLOR AW (1987) Chilling-enhanced photooxidation. The peroxidative destruction of lipids during chilling injury to photosynthesis and ultrastructure. Plant Physiol 83: 272-277

112. NIJVELDT RJ, VAN NOOD E, VAN HOORN EC, BOELENS PG, VAN NORREN K, VAN LEEUWEN 
PAM (2001) Flavonoids: a review of probable mechanisms of action and potential applications. Am J Clin Nutr 74: 418-425

113. BRAND-WILLIAMS W, CUVELIER ME, BERSET C (1995) Use of free radical method to evaluate antioxidant activity. Lebensm Wiss Technol 28: 25-30
114. HALVORSEN BL, HOLTE K, MYHRSTAD MC, BARIKMO I, HVATTUM E, REMBERG SF, WOLD AB, HAFFNER K, BAUGEROD H, ANDERSEN LF, MOSKAUG O, JACOBS DR Jr, BLOMHOFF R (2002) A systematic screening of total antioxidants in dietary plants. J Nutr 132: 461-471 